\title{
Analysis of Quality Control for Automatic Transmission Products MCVT Model By Six Sigma Approach at PT HPPM, Indonesia
}

\author{
Betrhriza Hanum $^{1}$, Ragil Pardiyono ${ }^{2,}$ Andy Kurniawan ${ }^{3}$ \\ ${ }^{1}$ Industrial Engineering Department, Faculty of Engineering, Universitas Mercu Buana \\ ${ }^{2}$ Industrial Engineering Department, Faculty of Engineering, Universitas Jendral Ahmad Yani \\ ${ }^{3}$ Engineer, PT HPPM, Indonesia
}

\begin{abstract}
PT HPPM is a manufacturing company engaged in the automotive sector. The products produced include Automatic Transmission (ATM), Engine Valve (EV), Four Wheel Drive (4WD), and Stell Belt, which are marketed at home and abroad. In carrying out its production activities, PT HPPM has guidelines for controlling its products' quality to compete in the automotive industry, including ATM products with the MCVT (Medium Continuously Variable Transmission) model. The method used in the quality control analysis of this research is Six Sigma, a vision of quality improvement towards a target of 3,4 failures per million opportunities for every transaction of goods and services, Gasperz (2005). To apply the Six Sigma concept, a measurement method is needed to assist the implementation of Six Sigma in the company. There are five steps in this method's stages, namely DMAIC (Define, Measure, Analyze, Improve, Control).

There are four potential Critical To Quality (CTQ) that cause the product to become defective or fail in the MCVT model, namely NG Leak, NG Gata, NG Circlip, and NG OPC. The highest defect is NG Leak defect, 127 units with a percentage of 45.68\% of the total number of defects produced-then followed by defects NG Gata with 79 units with a percentage of 28.42\%. Meanwhile, another defect is NG Circlip, with 62 units with a percentage of 22.30\%, then NG OPC as many as ten units with a percentage of $3.60 \%$.

By using the Six Sigma method and the DMAIC step (Define, Measure, Analyze, Improve, Control), it can be seen that the quality of MCVT products in the Main Line 1 process is good, which is at the level of 4,876 sigma with 370 Defect Per Million Opportunity (DPMO). From the Define stage by mapping and identifying problems to find out the causes of defective products, the Measure Stage by calculating the stability of the poses using the SPC method to determine the Proportion, CL, UCL, and LCL and calculating the process capability to determine the sigma level value and the DPMO value. The Analyze stage identifies the source of the problem with the Fishbone Diagram, the Improve stage looks for solutions using the 5W1H method, then Control to maintain and maintain process improvements. The results showed a decrease in the DPMO value from 383 units to 370 and an increase in the sigma level value from 4,868 to 4,876. This shows that the company has been able to implement a good quality control system.
\end{abstract}

Keywords: Quality Control, Six Sigma, DMAIC, Defective Products.

\section{INTRODUCTION}

The Indonesian automotive industry has become an essential pillar in the country's manufacturing sector as many world-renowned car companies have opened car manufacturing plants or increased their production capacity in Indonesia, the largest economy in Southeast Asia. Moreover, Indonesia is experiencing a tremendous transition as it has changed from merely being a car production site to being exported to a large car sales market due to an increase in per capita domestic product. Every industry, be it trade, service, or manufacturing industry, always carries out various activities. Each company will have a different calculation method, especially manufacturing companies that produce raw materials into finished goods. Things that need to be considered in manufacturing companies' applications are the suitability and compatibility of the system itself with the company's activities.

Every company would want to increase profits, especially from its operating activities. Therefore, every manager of the company will make decisions aimed at getting high profits. Business strategies to increase competitive advantage can be done by improving quality. Companies that use quality as a strategic tool will have the advantage of competing against their competitors in 
controlling the market because not many companies can achieve quality superiority. In this case, the company must produce products with high quality, competitive prices, and on-time delivery.

Production processes that pay attention to quality will produce products that are free from damage or defects. This can avoid waste in terms of time, cost, and labor so that the unit production costs can be reduced and product prices can be more competitive. Six Sigma is a quality approach to Total Quality Management (TQM). TQM came to the United States' attention in the 80s, and it was a response to the superiority of Japanese manufacturers in the field of Automotive and Air Conditioning. Many studies in air conditioning have found that there are more defects in US companies than Japanese companies. In general, quality control systems such as TQM and others only emphasize continuous improvement efforts based on management's independent awareness. The system does not provide the right solution regarding the breakthroughs that should be made to produce a dramatic quality increase towards a failure rate of $=0$ (zero defect).

Six Sigma as a popular method is an alternative in quality control principles, which is a breakthrough in the field of quality management; Six Sigma can be used as a measure of industrial system performance that allows companies to make extraordinary improvements with actual strategic breakthroughs, six Sigma. It can also be viewed as a customer-focused industrial process control concerning process capability. Achievement of Six Sigma is only 3.4 disabilities per million opportunities. The higher the sigma target achieved, the better the industrial system performance is. PT HPPM is a manufacturing company engaged in the automotive sector. The products produced include Automatic Transmission (ATM), Engine Valve (EV), Four Wheel Drive (4WD), and Stell Belt, which are marketed at home and abroad. In carrying out its production activities, PT HPPM has guidelines for controlling the quality of its products to compete in the world of the automotive industry. In this study, the authors will examine the quality control of the Automatic Transmission (ATM) type MCVT, which is a new model of ATM products. With the Six Sigma method, it can be seen to what extent control the quality of the MCVT model ATM products so that it can be a reference for continuing to strive for quality superiority. By achieving good quality, it can reduce production costs.

\section{LITERATURE SURVEY}

\subsection{Six Sigma}

Six Sigma is a quality improvement method widely used by companies and organizations globally by promoting the concept that there will only be 3.4 product defects for every 1 million products produced. The pioneering companies in the application of Six Sigma are General Electric and Motorolla, which are finally able to improve the company's condition for the better by applying this method.

In short, the definition of Six Sigma, according to Gasperz (2005) Six Sigma, is a vision of improving quality towards a target of 3,4 failures per million opportunities for every transaction of goods and services. So Six Sigma is a method or technique of controlling and dramatic quality improvement, which is a breakthrough in quality management.

To make customers satisfied, the company must provide the value expected by the customers. If the product is processed by the Six Sigma method, the company may expect 3.4 failures per million opportunities or expect 99.99966 percent of what customers expect in the product. According to Gasperz (2005), six key aspects need to be considered in the application of the Six Sigma concept, namely:

1. Customer identification

2. Product identification

3. Identification of needs in producing products for customers

4. Process Definition

5. Avoiding mistakes in the process and eliminating all existing waste

6. Improve the process continuously towards Six Sigma targets

Six aspects need to be considered if the Six Sigma concept is to be determined in the manufacturing field (Gazperz, 2005):

1. Identify product characteristics that satisfy customers (according to customer needs and expectations)

2. Classify all quality characteristics as individual CTQ (Critical To Quality).

3. Determine whether each CTQ can be controlled through material control, work process machines, and others.

4. Determine the maximum tolerance limit for each CTQ as desired by the customer (determine the UCL and LCL from each CTQ)

5. Determine the maximum process variation for each CTQ (determine the maximum standard deviation value for each CTQ)

6. Change the product and process design in such a way as to achieve the Six Sigma target values.

\section{OBJECTIVE OF THE RESEARCH}

By the problems faced, the objectives of this study are:

1. Analyzing the quality control of MVCT type products at PT HPPM using the six sigma approach. 
2. Identify the factors that cause defects or abnormal products of the MCVT type at PT HPPM.

\section{RESEARCH METHODOLOGY}

To obtain data in order to achieve the objectives of this study, the authors used several data collection techniques, including:

1. Observation

In this observation, the authors collect data directly by using the five senses to observe the situation or condition of the production process and observe the causes of product failure.

2. Interview

The author conducted face-to-face interviews and conducted a direct question and answer with resource persons, QC, Shift Leader, and operators to gather information.

3. Documentation

The author records all the data and production process activities that have been obtained to achieve the objectives of this study

Data processing is done from the data that has been obtained are:

1. Determining Critical to Quality (CTQ)

2. Measure process stability

3. Calculation of Defect Per Million Opportunity (DPMO)

4. Calculation and measurement of the Sigma levele. Calculating the total cost of raw material supplies

\section{RESULT AND DISCUSSION}

After collecting and processing data, the results obtained from several data processing show differences in values before and after the research.

Analysis of the Results of Improvement of DPMO Value and Sigma Level

Based on applying the Six Sigma method, the sigma value and DPMO (Defect Per Million Opportunities) are obtained. Table 1 below compares the sigma and DPMO values before and after the study will be displayed.

Table 1 Comparison of DPMO and Sigma Level values

\begin{tabular}{|l|c|c|c|c|}
\hline Condition & DPMO & Sigma Value & OK Product & NG products \\
\hline Before Research & 383 & 4,868 & $99,96170 \%$ & $0,03830 \%$ \\
\hline After Research & 370 & 4,876 & $99,96300 \%$ & $0,03700 \%$ \\
\hline
\end{tabular}

From table 1, it can be seen that there was a decrease in the DPMO value from 383 units to 370 and an increase in the sigma level value from 4,868 to 4,876 . This indicates a change in the value of quality after research. However, the change in value is only a little, but this is very meaningful for improving product quality towards zero defects.

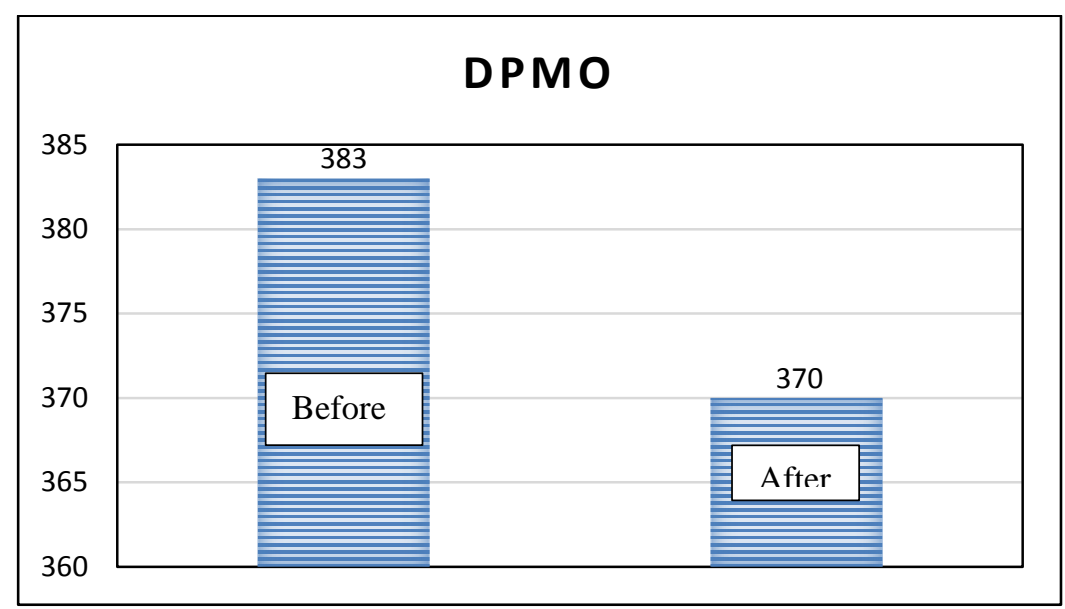

Figure 1 Comparison of DPMO Value

Figure 1 shows a decrease in the value of DPMO after the study, from 383 units to 370 units. 


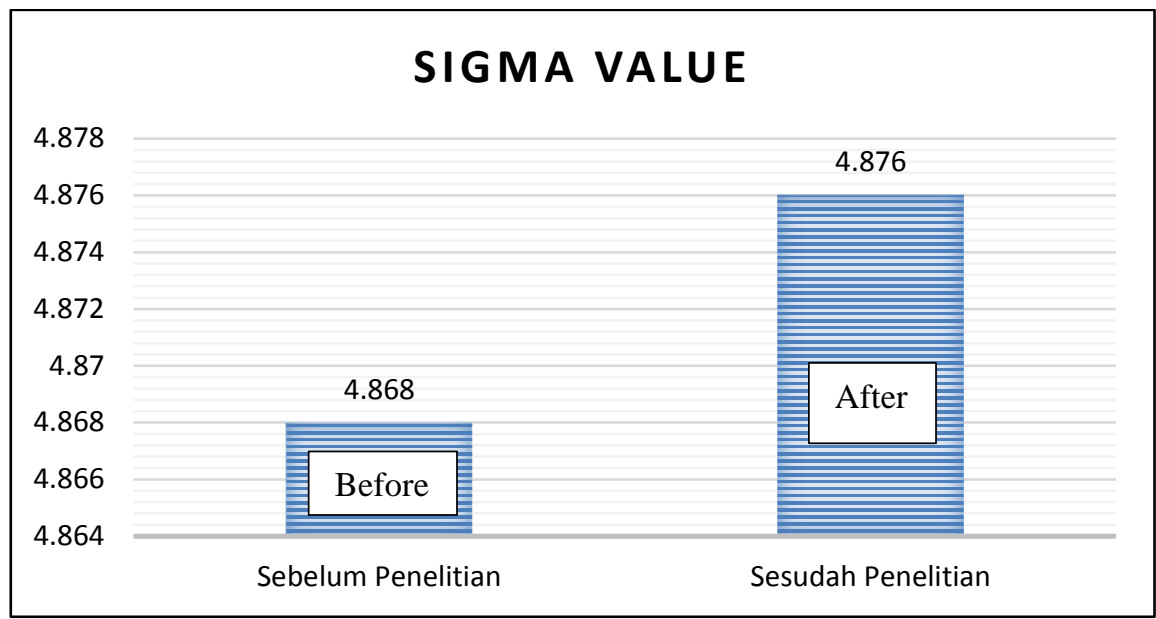

Figure 2 Comparison of Sigma Level Values

Figure 2 shows an increase in the sigma level value after researching 4,868 to 4,876 .

Analysis of Fishbone Diagram Results

Based on the Fishbone Diagram application to help solve existing problems, several factors still need attention and improvement. From the data obtained, the factors that need to be improved include

1. Human

In this human factor, several problems need to be fixed, including the lack of discipline and responsibility of operators in complying with company rules, especially complying with SOP and WI in the production process, resulting in defective products. 2. Machines

In the machine factor, there is negligence on the operator and engineering part as the person in charge of the machine condition. The operator does not immediately report to the superior if there is an abnormal condition in the machine or jig. Meanwhile, Engineering does not regularly control engine failure or jig results in defective products.

3. Method

In the method factor, there are still weaknesses in carrying out the checking process, namely only by using a visual check-in the checking process where the visual check method depends on the operator's conditions. For example, drowsiness, tiredness, or feeling unwell.

4. Material

In the material factor, cases of Box Part are still found, there is still dirt which significantly affects the quality of the parts themselves, and there are still materials or parts that are not standard passed to the Dept Assembly

5. Environment

In environmental factors, there are obstacles to the problem of lighting for checking markers from workpieces.

5W1H Results Analysis

Based on research using the $5 \mathrm{~W} 1 \mathrm{H}$ method in problem-solving, several suggested improvements are needed to improve product quality.

Table 2 Proposed Remedies for NG Leak

\begin{tabular}{|c|c|}
\hline Defect & Proposed Improvement \\
\hline \multirow{5}{*}{$\begin{array}{l}\mathrm{NG} \\
\text { Leak }\end{array}$} & $\begin{array}{l}\text { a. Clean and check the piston before } \\
\text { installing clean the piston holder }\end{array}$ \\
\hline & Cleaning Piston storage \\
\hline & Revise the SOP and WI \\
\hline & $\begin{array}{l}\text { b. Provide training again to be more } \\
\text { responsible and more thorough in working }\end{array}$ \\
\hline & $\begin{array}{l}\text { Provide motivation and understanding of } \\
\text { the importance of Quality }\end{array}$ \\
\hline
\end{tabular}




\begin{tabular}{|l|l|}
\hline Defect & \multicolumn{1}{|c|}{ Proposed Improvement } \\
\hline & $\begin{array}{l}\text { c. Confirmation and Quality assurance } \\
\text { from the Die Casting and Aluminum } \\
\text { Department to further tighten Quality so } \\
\text { that NG goods do not flow back to the } \\
\text { Assembly }\end{array}$ \\
\hline
\end{tabular}

Table 3 Proposed Remedies for NG Leak (continued)

\begin{tabular}{|c|l|}
\hline Defect & \multicolumn{1}{|c|}{ Proposed Improvement } \\
\hline \multirow{1}{*}{ NG } & $\begin{array}{l}\text { d. The 6x12 BF has not been fastened } \\
\text { because the QL is not placed on the next } \\
\text { pallet, reprimands and provides re- } \\
\text { training to the relevant operator. }\end{array}$ \\
\cline { 2 - 3 } & $\begin{array}{l}\text { perform marking check process with } \\
\text { marker against BF 6x12 }\end{array}$ \\
\cline { 2 - 3 } & $\begin{array}{l}\text { e. Provide instructions to the operator } \\
\text { regarding the installation of the oring and } \\
\text { add check markings with a marker }\end{array}$ \\
& \\
\hline
\end{tabular}

Tables 2 and 3 present the proposed process improvements to solve the NG leak problem.

Table 4 Proposed Improvements for NG Gata

\begin{tabular}{|c|l|}
\hline Defect & Proposed Improvement \\
\hline \multirow{1}{*}{ NG } & $\begin{array}{l}\text { a. The cause of the problem is that the shim } 26 \\
\text { is stuck, so a shim } 26 \text { gauge is needed before } \\
\text { it is installed }\end{array}$ \\
\cline { 2 - 3 } Gata & $\begin{array}{l}\text { b. Added the process of checking the } \\
\text { cleanliness of the shim before installing and } \\
\text { controlling the cleanliness of the shim box } 26\end{array}$ \\
\cline { 2 - 3 } & $\begin{array}{l}\text { c. Shim 26 is not installed / double installed } \\
\text { due to negligence of the pure operator because } \\
\text { there is already a check so the operator must } \\
\text { be given training and re-understanding the } \\
\text { importance of quality. Accompanied by } \\
\text { control. }\end{array}$ \\
\hline
\end{tabular}

Table 4 describes the proposed improvements to solve the NG Data problem. 
Table 5 Proposed Improvements for NG Circlip

\begin{tabular}{|c|l|}
\hline Defect & $\begin{array}{l}\text { Proposed Improvement } \\
\text { a. Mizo (where the ex29 circlip is installed on } \\
\text { the Pulley shaft) has damage such as cracks } \\
\text { and bumps so you have to confirm to the Dept. } \\
\text { Pulley to improve Quality control so that NG } \\
\text { goods don't flow }\end{array}$ \\
\cline { 2 - 3 } Nirclip & $\begin{array}{l}\text { b. Controlling and changing the jig } \\
\text { periodically and always checking the jig every } \\
\text { shift change }\end{array}$ \\
\cline { 2 - 4 } & $\begin{array}{l}\text { c. Instruct the operator to be more careful and } \\
\text { concentrate while working so that they can } \\
\text { find abnormal conditions such as dirt on the } \\
\text { workpiece }\end{array}$ \\
\hline
\end{tabular}

Table 5 describes the proposed improvements to solve the NG Circlip problem.

Table 6 Proposed Improvements for NG OPC

\begin{tabular}{|l|l|}
\hline Defect & Proposed Improvement \\
\hline \multirow{2}{*}{ NG } & $\begin{array}{l}\text { a. In SOP and WI, there is no marker check } \\
\text { process, so a check marker must be revised } \\
\text { and added because the OPC marker color is } \\
\text { faint }\end{array}$ \\
\cline { 2 - 3 } & $\begin{array}{l}\text { b. Add lights to this process so that the } \\
\text { lighting is brighter than usual. }\end{array}$ \\
\hline
\end{tabular}

Table 6 describes the proposed improvements to solve the NG OPC problem.

\section{CONCLUSION}

Based on data that has been analyzed and discussed in the previous chapter, the authors draw the following conclusions:

1. Using the Six Sigma method shows that the quality of MCVT products in the Main Line 1 process is fair. Level 4,876 sigma with 370 Defect Per Million Opportunity (DPMO), with OK products of $99.96300 \%$ and NG products of $0.03700 \%$. With the results of this study, the company can find out and control the value of the quality implementation that has been implemented with the Sigma level so that the company can monitor and control the quality towards (0) zero defect.

2. From the analyzed factors based on machines, methods, humans, materials, and the environment. It can be concluded that there is still a need for an understanding of quality for all employees, from operators to staff, so that they care more about quality and can comply with the SOP and WI that have been set by the company to achieve the target, namely (0) zero defect.

\section{Suggestion}

From the results of the discussion and research conclusions, several suggestions can be considered by the company:

1. Machine 
There are worn jigs that should have been replaced to maintain product quality. By controlling and changing the jig periodically and always checking the jig every shift change. As well as instructing the operator to report any abnormal events on the machine or jig immediately.

2. Method

Adding a checking method that previously only used visual checks, then added by checking markers using markers on the object being checked to provide quality assurance on the product.

3. Humans

It is necessary to increase employee skills and job training. Also, employees in each process need to be motivated to improve performance to achieve good quality. Providing understanding to all employees about the importance of quality for the continuity of the company and the need to give awards to outstanding employees as motivation

4. Material

Companies are expected to be more selective and to tighten the selection of raw materials from suppliers. Confirm and cooperate with other Departments to prevent NG products from flowing to the Assembly Department

5. Environment

Lights are needed for processes that require more lighting than other processes to maintain product quality.

\section{ACKNOWLEDGMENT}

Universitas Mercu Buana Research Centre funded this research. We are grateful for all experts who are willing to be research partners, with no mention of the company name.

\section{REFERENCES}

1. Haekal, J., Hanum, B., \& Adi Prasetio, D. E. 2020. Analysis of Operator Body Posture Packaging Using Rapid Entire Body Assessment (REBA) Method: A Case Study of Pharmaceutical Company in Bogor, Indonesia. International Journal of Engineering Research and Advanced Technology - IJERAT (ISSN: 2454-6135), 6(7), 27-36.

2. Hanum, B., Haekal, J., \& Adi Prasetio, D. E. . 2020. The Analysis of Implementation of Enterprise Resource Planning in the Warehouse Division of Trading and Service Companies, Indonesia . International Journal of Engineering Research and Advanced Technology - IJERAT (ISSN: 2454-6135), 6(7), 37-50.

3. Kholil, M., Haekal, J., Eko Adi Prasetio, D. ., \& Sulaiman Hasan. 2020. The Lean Manufacturing Design For Improving Production Scheduling Using Product Wheel Method in Chemical Manufacturing Company, Indonesia. International Journal of Engineering Research and Advanced Technology - IJERAT (ISSN: 2454-6135), 6(8), 12-18.

4. Haekal, J., \& Setio, H. 2017. Selection of Raw Material Suppliers Using Analytical Hierarchy Process in Food and Beverage Company, South Jakarta. ComTech: Computer, Mathematics and Engineering Applications, 8(2), 63-68.

5. HAEKAL, J. (2018). PERANCANGAN DAN EVALUASI IMPLEMENTASI SISTEM MANAJEMEN MUTU ISO 9001: 2015 MELALUI KEPUASAN PELANGGAN DI UNIVERSITAS ISLAM AS-SYAFI'IYAH (Doctoral dissertation, Universitas Mercu Buana Jakarta).

6. Kholil, M., Haekal, J. H, Sulaiman. 2020. Lean Manufacturing Design to Reduce Waste in Gear Production Process Using VSM and Kaizen Method Approaches (Case Study: Gear Primary Driven K56 Product). Journal of Scientific and Engineering Research. 7(8), 1-9

7. Haekal, J., Hanum, B., \& Adi Prasetio, D. E. 2020. Application of Quantitative Strategic Planning Matrix (QSPM) For Determination of Alternative Strategies in Food and Beverage SMES in Bogor Indonesia. Journal of Scientific and Engineering Research. 7(7), 137-145

8. Hanum, B., Haekal, J., \& Adi Prasetio, D. E. . 2020. SPHC Material Inventory Control Analysis in Project VL01 Centralized by the EOQ Method in Automotive Company Indonesia. Journal of Scientific and Engineering Research. 7(7), 130-136

9. Andiana, M. (2017). Aplikasi Metode EOQ Dalam Pengendalian Persediaan Bahan Baku PT X. Jurnal Akuntansi Maranatha, Vol. 10(1), Hal. 31.

10. Syukron, Amin \& Kholil, Muhammad.2013. Pengantar Teknik Industri. GRAHA ILMU. Yogyakarta.

11. Pete \& Holpp.2002. What Is Six Sigma. ANDI. Yogjakarta.

12. Gaspersz, Vincent. 2005. Total Quality Management. PT Gramedia Pustaka Utama. Jakarta.

13. E.Wood Buffa.1989. Manajemen Produksi dan Operasi. Edisi keenam Jilid kedua. Erlangga. Jakarta 
14. Sukardi.,Usman Effendi dan Diyah Ayu Astuti. 2011. “Aplikasi Six Sigma pada Pengujian Kualias Produk di UKM Keripik Apel Tinjauan dari Aspek Proses”, Jurnal Teknologi, Volume 12 Nomor 1.

15. Rendy Kaban. 2104. "Pengendalian Kualitas Kemasan Plastik Pouch menggunakan Statisticl Procces Control (SPC) di PT INCASARI RAYA PADANG” Jurnal Optimasi Sistem Industri, Volume 13 Nomor 1.

16. Ibrahim Ghifari, Ambar Harsono dan Abu Bakar.2013.”Analisa Six Sigma untuk Mengurangi Jumlah Cacat di Station Kerja Sablon (Studi Kasus: CV.Miracle)". Jurnal Online Institut Teknologi Nasional.Volume 1 Nomor 1

EMAIL: bethriza@mercubuana.ac.id 